\title{
Hledání optimální podoby realizace environmentální výchovy na prvním stupni Zš
}

\author{
Kateřina Jančaříková \\ Envigogika 2009/IV/1 - Recenzované články/ Reviewed Papers \\ Publikováno/Published 31. 05. 2009 \\ DOI: http://dx.doi.org/10.14712/18023061.36
}

\begin{abstract}
Abstrakt:
Výzkum prezentovaný $v$ tomto př́spěvku vznikl jako část rozsáhlé výzkumné práce zaměřené na environmentální výchovu na prvním stupni ZŠ $\vee$ České republice. Tento výzkum probíhal metodou zakotvené teorie Sběr pojmů ${ }^{1}$ mezi selektivně vybranou skupinou respondentů. Jeho výsledkem je do tabulky uspořádaný výčet všeho toho, co by do realizace environmentální výchovy na prvním stupni mělo $v$ ideálním prípadě patřit. Tento výčet byl komparován s Ekopedagogovým osmerem, průřezovým tématem Environmentální výchova RVP ZV. Posloužil k vytvoření Metodického pokynu MŠMT k EVVO (ř́jen 2008). Výsledek výzkumu je možné použít pro odbornou diskusi cílů, obsahu, podmínek vyučování, prostředků, metod i kompetencí učitelů (lektorů) environmentální výchovy ale také k vytvoření nástroje evaluace, resp. autoevaluace.
\end{abstract}

\section{Klíčová slova:}

Environmentální výchova, ekologická výchova, primární vzdělávání, Zakotvená teorie

\section{Abstract:}

The research presented in this article was created as part of an extensive research paper directed at environmental education at the first stage of elementary school education in the Czech Republic (children aged 6-11). The research paper was recently published as a Ph.D. thesis.

The research was conducted using Grounded Theory and its Term Collection method among a group of selectively determined subjects. The result is a table listing all categories of educational goals, methods and prerequisites that should be ideally be included in the environmental education practice at the first-stage elementary school level. The list has been compared with the Eco-Teacher Eightfold (Ekopedagovo osmero), the Environmental Education Cross-cutting theme in the Environmental Education Framework Guidelines (Průřezové téma Environmentální výchova RVP ZV) and other documents existing in the Czech Republic. The results of the research can be used to sprout an expert discussion of targets, content, teaching conditions and aids, methods, and environmental education teacher (educator) competences. It served to create Methodological guidance for

1 Pozn. ed.: více o této metodě viz Kateřina Jančaříková: Žákovské portfolio - vhodná forma hodnocení environmentální výchovy. Envigogika, 2/2007/3 
the Ministry of Education EVVO (October 2008). The results can also be used to create tools for evaluation or self-evaluation in environmental education.

\section{Key words:}

Environmental education, primary education, $\mathrm{K}-12$, Grounded Theory 


\section{Úvod}

Školský zákon přijatý v roce 2004 s účinností od 1. ledna 2005 oficiálně završil českou kurikulární reformu, která byla započata v roce 2001 přijetím tzv. Bílé knihy. Pro každý obor vzdělávání $v$ základním a středním vzdělávání a pro předškolní, základní umělecké a jazykové vzdělávání se vydávají rámcové vzdělávací programy. Rámcové vzdělávací programy (RVP) vymezují povinný obsah, rozsah a podmínky vzdělávání, jsou závazné pro tvorbu školních vzdělávacích programů, hodnocení výsledků vzdělávání dětí a žáků, tvorbu a posuzování učebnic. Rámcový vzdělávací program pro základní vzdělávání (RVP ZV) obsahuje Environmentální výchovu jako jedno z šesti průřezových témat.

Stačí ale učitelům RVP ZV jako vodítko pro kvalitní realizaci environmentální výchovy? Jan Činčera se domnívá, že nikoli. Ve své analýze ukazuje, že český standard pro environmentální výchovu na základních školách není kompatibilní s mezinárodními standardy, je jen částečně vnitřně integrovaný, je hodnotově neutrální a nekoresponduje s teoriemi proenvironmentálního chování (Činčera, 2009).

Environmentální výchova $v$ ČR je (naštěstí) širší a pestřejší, než je popsáno v RVP ZV. Česká environmentální výchova nese všechny znaky tzv. "dobré školy" - má tradici, učitele, nestory, kontakty v zahraničí, historii a budoucnost (Činčera, 2007). Její vlastní vývoj, a především významné společenské změny, ke kterým v posledních desetiletích u nás i ve světě došlo, podpořily proces směřující od hnutí nebo dobré školy k etablování nového vědeckého oboru. $V$ rámci tohoto procesu vznikla disertační práce zaměřená právě na environmentální výchovu na prvním stupni ZŠ a tento příspěvek prezentuje jeden z výzkumů (Sběr ÉČEK) uskutečněný v rámci této práce (Jančaříková, 2008: str. 90-94) .

\section{Metodologie}

\section{Metoda}

Vzhledem k cíli výzkumné práce byla jako hlavní výzkumná metoda zvolena kvalitativní metoda zakotvené teorie (Strauss, Corbin, 1998). Zakotvená teorie je moderní metodou kvalitativního výzkumu. Kvalitativní výzkum je druh pedagogického výzkumu rozvíjený od 60 . let 20. stol. a je založený na jiných metodologických postupech než výzkum „klasický". Někdy bývá nazýván „postpozitivistický" nebo "naturalistický". Zdrojem dat je v kvalitativním výzkumu přirozené prostředí. Kvalitativní výzkum klade důraz na výklad zkoumaných jevư očima samotných aktérů. Záměrem kvalitativního výzkumu je vytvoření komplexního, holistického obrazu o zkoumaném jevu. $V$ tomto príspěvku je představen ovšem jen jeden (základní) výzkum ( $v$ disertační práci nazvaný První etapa výzkumu - sběr pojmů za účelem vytvoření hlavní linie práce čili "Sběr ÉČEK"), který řeší široce formulovanou hlavní výzkumnou otázku: "Co patři do environmentální výchovy na prvním stupni základních škol?".

\section{Sběr pojmů čili "sběr ÉČEK"}

Výzkumným cílem Sběru pojmů bylo získat pojmy = výčet všeho, co patří do environmentální výchovy na prvním stupni základních škol. Pojmy byly na doporučení A. Strausse a J. Corbinové (1999: str. 47-48) pojmenovány autentickým popularizujícím a snadno zapamatovatelným názvem: „ÉČKA".

V našich podmínkách podobný, výzkumem získaný kompletní výčet všeho, co by mělo patřit do environmentální výchovy na prvním stupni, dosud udělán nebyl. Existují ovšem různé materiály středisek ekologické výchovy (SEV), se kterými Ize výsledný komplet ÉČEK porovnávat. Nejpropracovanější z nich je Ekopedagogovo osmero A. Máchala (Máchal, 2000). Další komparace se nabízí také s obsahem prưřezového tématu Environmentální výchova v 6. kapitole Rámcového vzdělávacího programu základního 
vzdělávání (2004) a publikací Teorie a metodika ekologické výchovy H. Horké (1996), která se věnuje především environmentální výchově na prvním stupni ZŠ.

Samotný výčet pojmů Ize považovat za významný výsledek. Ve kontextu celé výzkumné práce (Jančaříková, 2008) však výčet pojmů tvoří "pouhou" linii práce strukturu, na kterou byl navázán další výzkum a na níž byla vystavěna teorie environmentální výchovy na prvním stupni ZŠ.

ÉČKA byla získána na základě rozhovorů (osobních, telefonických resp. po ústní domluvě na žádost respondenta i písemných - e-mailem) s experty na environmentální výchovu na prvním stupni ZŠ.

Za experta byl považován ten, kdo strávil pět let nebo více prací ve speciální činnosti (viz níže). Expertưm byla kladena základní výzkumná otázka: „Co všechno podle vašeho názoru patři do environmentální výchovy na prvním stupni?", která byla v pozdějších fázích výzkumu upřesňována: "Vyjmenujte prosím přednostně to, co vy osobně považujete za nejdůležitější, a také to, na co se podle vás někde zapomíná.

Výběr expertů byl prováděn nenáhodně (tj. jednalo se o selektivní výběr), který probíhal mezi těmito čtyřmi skupinami:

- „šikovní" učitelé/učitelky z prvního stupně se silným vztahem k přírodě,

- učitelé environmentální výchovy na pedagogických vyšších a vysokých školách,

- $\quad$ pracovníci středisek ekologické výchovy, ekocenter a nevládních organizací, kteří zajištují programy environmentální výchovy pro žáky prvního stupně

- $\quad$ ekologičtí aktivisté - rodiče dětí na prvním stupni ZŠ;

tedy ve skupinách, u nichž Ize předpokládat, že respondenti mají zájem o danou problematiku, že se $v$ této oblasti orientují a zároveň mají praktickou zkušenost $s$ dětmi ve věku žáků prvního stupně (6 - 12 let).

V jednotlivých skupinách byli experti (přehled viz tabulka 1) oslovováni tak, aby bylo vyloučeno jejich případné vzájemné ovlivňování; tak byl zaručen předpoklad získání pestrého názorového spektra (a rychlejší teoretické nasycení vzorku²). Např. pokud byli oslovováni pedagogové, tak vždy z různých základních škol, pokud zaměstnanci středisek environmentální výchovy (SEV), tak vždy z různých SEV, pokud vysokoškolští pedagogové, tak z rưzných vysokých škol atd. Popsaný postup (selektivní výběr) není nezbytný, je jen praktický (urychlil okamžik teoretického nasycení vzorku).

\footnotetext{
2 Teoretické nasycení vzorku je termín metody zakotvené teorie. Jedná se o název stavu, kdy další respondenti nepřinášejí v rozhovorech nové pojmy.
} 
Tabulka 1. Přehled oslovených expertů, jejich profesí a pracovišt', resp. bydlišt'.

\begin{tabular}{|c|c|c|c|}
\hline $\begin{array}{l}\text { Skupina } 1 \\
\text { „Šikovné" učitelky } \\
\text { z prvního stupně } \\
\text { se silným vztahem } \\
\text { k př́rodě }\end{array}$ & $\begin{array}{l}\text { Skupina } 2 \\
\text { Učitelé } \\
\text { environmentální } \\
\text { výchovy na } \\
\text { pedagogických } \\
\text { vyšších } \\
\text { a vysokých školách }\end{array}$ & $\begin{array}{l}\text { Skupina } 3 \\
\text { Pracovníci SEV, } \\
\text { ekocenter a } \\
\text { nevládních } \\
\text { organizací, kteří } \\
\text { zajišt́ují programy } \\
\text { EV pro žáky prvního } \\
\text { stupně }\end{array}$ & $\begin{array}{l}\text { Skupina } 4 \\
\text { Ekologičtí aktivisté - } \\
\text { rodiče dětí na prvním } \\
\text { stupni ZŠ }\end{array}$ \\
\hline $\begin{array}{l}\text { A.J. } \\
\text { ZŠ, Kladno }\end{array}$ & $\begin{array}{l}\text { H.K. } \\
\text { Vyšší pedagogická } \\
\text { škola, Svatý Jan pod } \\
\text { Skalou }\end{array}$ & $\begin{array}{l}\text { M.D. } \\
\text { Hnutí Brontosaurus, } \\
\text { Jeseník }\end{array}$ & $\begin{array}{l}\text { H.B. } \\
\text { viceprezident českého } \\
\text { regionu IEF } \\
\text { (International } \\
\text { Ecumenical } \\
\text { Fellowship), Praha }\end{array}$ \\
\hline $\begin{array}{l}\text { Eva } 1 \\
\text { ZCŠ, Praha }\end{array}$ & $\begin{array}{l}\text { H.H. } \\
\text { Masarykova univerzita } \\
\text { Brno }\end{array}$ & $\begin{array}{l}\text { K.B. } \\
\text { Chaloupky, Jihlava }\end{array}$ & $\begin{array}{l}\text { M.B. } \\
\text { Hnutí duha, Volary }\end{array}$ \\
\hline $\begin{array}{l}\text { P.S. } \\
\text { DŠ, Český Brod }\end{array}$ & $\begin{array}{l}\text { E.L. } \\
\text { PedF UK, Praha }\end{array}$ & $\begin{array}{l}\text { K.Č. } \\
\text { Podblanické } \\
\text { ekocentrum } \\
\text { Vlašim }\end{array}$ & $\begin{array}{l}\text { T.F. } \\
\text { Botanický ústav } \\
\text { Průhonice, Praha }\end{array}$ \\
\hline $\begin{array}{l}\text { J.Š. } \\
\text { speciální pedagog } \\
\text { a učitelka, Praha }\end{array}$ & $\begin{array}{l}\text { V.Ž. } \\
\text { PřF UK, Praha }\end{array}$ & $\begin{array}{l}\text { E.S. } \\
\text { Toulcův dvůr, Praha }\end{array}$ & $\begin{array}{l}\text { M.H. } \\
\text { Ekologická sekce ČKA, } \\
\text { Praha }\end{array}$ \\
\hline & & $\begin{array}{l}\text { A.B. } \\
\text { Podhoubí, Praha }\end{array}$ & $\begin{array}{l}\text { J.H. } \\
\text { dříve Hnutí } \\
\text { Brontosaurus, nyní } \\
\text { "ekopodnikatel", } \\
\text { Černošice }\end{array}$ \\
\hline & & & $\begin{array}{l}\text { M.J. } \\
\text { alternativní (TUR) } \\
\text { životní styl, } \\
\text { Volyně }\end{array}$ \\
\hline & & & $\begin{array}{l}\text { J.Si. } \\
\text { Hnutí duha, SKAV aj. }\end{array}$ \\
\hline & & & $\begin{array}{l}\text { J.St. } \\
\text { alternativní životní styl } \\
\text { (jedna z respondentek } \\
\text { výzkumu H. Librové) }\end{array}$ \\
\hline
\end{tabular}


Sběr pojmů (ÉČEK) byl v souladu s metodikou zakotvené teorie (Strauss, Corbinová, 1999) ukončen, když další experti nepřinášeli nové pojmy, čili došlo k tzv. teoretickému nasycení vzorku. Sběr pojmů (ÉČEK) probíhal v letech 2006 - 2007.

Následně byly pojmy (ÉČKA) syntézou a analýzou kategorizovány, a byly vytvořeny pracovní subkategorie a pracovní verze tabulky.

Pracovní verze tabulky byla zaslána dříve osloveným expertům, aby se k ní vyjádřili a doporučili její úpravy. Konečná verze tabulky (tabulka 2) byla vytvořena na základě těchto doporučení.

\section{Výsledky}

K teoretickému nasycení došlo, když bylo získáno více než 80 ÉČEK a uskutečněno jednadvacet rozhovorů s experty.

Klasifikace ÉČEK byla poměrně snadná (koše na separovaný odpad, možnost recyklace a další ÉČKA byla např. sloučena pod možnost separace odpadu). Roztřídění ÉČEK do kategorií a subkategorií bylo složitější, protože některé pojmy, tak jak je experti vyslovili, byly zároveň cílem i prostředkem environmentální výchovy. ÉČKA byla syntetizována a analyzována a roztříděna do těchto kategorií: obsah environmentální výchovy, podmínky pro environmentální výchovu a její vyučování, cíle environmentální výchovy, prostředky environmentální výchovy a učitel environmentální výchovy. Lze si samozřejmě představit i jiné uspořádání. Na výzvu k diskusi o pracovní verzi tabulky reagovalo pět respondentů (expertů). Tři reagovali obsáhle, jeden krátce a jeden se z rodinných důvodů omluvil. Podle nejvýznamnějších připomínek byla tabulka s přehledem ÉČEK upravena do konečné podoby (tabulka 2). Na základě připomínek respondentů byla především vytvořena tři nová ÉČKA (do "Vybavení třídy" bylo doplněno: časové schéma evoluce, do "Utváření zdravého životního stylu" bylo doplněno: vytvořit dostatečný časový prostor pro možnosti informálního vzdělávání, do "Dovedností" bylo doplněno: zaznamenávání). Jeden expert zpochybnil teoretické nasycení vzorku ("...dělá to na mě dojem, že ty jsi možná dalši EČKA nezískala, ale já je tam vidím."), přesto sám do pracovní tabulky doporučil přidání jediného ÉČ́KA (zaznamenávání) a jeho další úpravy byly drobné. Ani následné dva rozhovory s ním nepřinesly pro zakotvenou teorii další pojmy.

Celkově Ize shrnout, že kromě několika výše uvedených změn, experti se sebranými ÉČKY souhlasili, necítili potřebu je významněji doplňovat, vytvořené kategorie a subkategorie akceptovali. Jejich další doporučení byla spíše drobná, např. úprava ÉČKA "Využívat PC i TV" na "Využívat PC i TV, ale opatrně, aby se nevytvořil návyk, asi až od 3. třídy" nebo úprava ÉČKA "Vědět, co se v přírodě rozloží a co ne." na "Vědět, co se v prírodě rozloží a za jak dlouho, a co ne."

Tabulka 2 Seznam ÉČEK - výsledky výzkumů pro potřeby výzkumu

(přejato z Jančaříková, 2008).

\begin{tabular}{|l|l|l|}
\hline KATEGORIE & Subkategorie & Pojmy (ÉČKA) = to, co by v EV mělo být \\
\hline \multirow{2}{*}{ OBSAH } & $\begin{array}{l}\text { Legislativní zakotvení } \\
\text { obsahu } \\
\text { environmentální } \\
\text { výchovy. }\end{array}$ & $\begin{array}{l}\text { Návaznost na české kurikulární dokumenty - } \\
\text { především na RVP ZV. }\end{array}$ \\
\cline { 2 - 2 } & $\begin{array}{l}\text { Interdisciplinarita - vazby nejen } \\
\text { s prírodovědnými předměty, ale vlastně se } \\
\text { všemi ostatními (estetická výchova, pracovní } \\
\text { výchova aj. }\end{array}$ \\
\hline
\end{tabular}




\begin{tabular}{|c|c|c|}
\hline & & $\begin{array}{l}\text { Návaznost na nadnárodní dokumenty } \\
\text { a úmluvy. }\end{array}$ \\
\hline & & $\begin{array}{l}\text { Poznámka: } \\
\text { Experti nepovažovali za nutné vyjmenovávat } \\
\text { obsah určený RVP - shrnovali to do jediné } \\
\text { podmínky obsahu "závislost na RVP". } \\
\text { Soustředili se jen na to, co v RVP postrádají } \\
\text { a nebo na to, co chtěli zdůraznit (návaznost } \\
\text { na estetickou výchovu). Pro nastudování } \\
\text { celého obsahu je nutné mít na zreteli RVP ZV. }\end{array}$ \\
\hline \multirow{14}{*}{$\begin{array}{l}\text { PODMÍNKY } \\
\text { VYUČOVÁNÍ }\end{array}$} & \multirow{4}{*}{$\begin{array}{l}\text { Vyučování v terénu } \\
\text { - pod širým nebem } \\
\text { a v expozicích. }\end{array}$} & Neorganizovaný pobyt v přírodě. \\
\hline & & $\begin{array}{l}\text { Dostatečný časový prostor pro } \\
\text { možnost informálního vzdělávání. }\end{array}$ \\
\hline & & Organizovaný pobyt v př́rodě. \\
\hline & & $\begin{array}{l}\text { Exkurze na místa pro EV významná (čistírna } \\
\text { odpadních vod, spalovna, skládka, vodárna, } \\
\text { muzeum, skanzen, ZOO). }\end{array}$ \\
\hline & \multirow{10}{*}{$\begin{array}{l}\text { Vybavení třídy a školy } \\
\text { s ohledem } \\
\text { na obsah a cíle EV } \\
\text { a pravidla TUR. }\end{array}$} & $\begin{array}{l}\text { Podnětná a obměňující se výzdoba } \\
\text { z přírodních materiálů. }\end{array}$ \\
\hline & & Sbírky přírodnin. \\
\hline & & Možnost separace odpadu. \\
\hline & & PC i TV (ale opatrně - asi až od třetí třídy). \\
\hline & & Lupy, mikroskopy. \\
\hline & & Rostliny ve třídě/škole. \\
\hline & & Zvířata ve třídě/škole. \\
\hline & & $\begin{array}{l}\text { Časové schéma evoluce (lidé jsou na světě } \\
\text { krátce, ale zničili ho velmi). }\end{array}$ \\
\hline & & $\begin{array}{l}\text { Možnost záhonku pro každé dítě (aby si mohlo } \\
\text { sníst co si vypěstuje). }\end{array}$ \\
\hline & & $\begin{array}{l}\text { Zdravé stravování a dodržování zásad trvale } \\
\text { udržitelného života ve školní jídelně. }\end{array}$ \\
\hline \multirow{4}{*}{ CÍLE ${ }^{3}$} & \multirow{3}{*}{$\begin{array}{l}\text { Vážit si přirodního } \\
\text { a kulturního dědictví. }\end{array}$} & $\begin{array}{l}\text { Poznávat historii krajiny a získat k ní emoční } \\
\text { vztah. }\end{array}$ \\
\hline & & $\begin{array}{l}\text { Učit se vnímat přírodu v časových úsecích } \\
\text { přesahujících dosavadní žákův i lidský život. }\end{array}$ \\
\hline & & $\begin{array}{l}\text { Poznávat život předchozích generací, jejich } \\
\text { dědictví. }\end{array}$ \\
\hline & Chápat význam & Budovat uvědomění, že člověk je součástí \\
\hline
\end{tabular}

\footnotetext{
${ }^{3}$ Většina subkategorií Cílů byla vytvořena v souladů s RVP ZV.
} 


\begin{tabular}{|c|c|}
\hline \multirow{8}{*}{\begin{tabular}{|l|} 
a nezbytnost \\
udržitelného rozvoje.
\end{tabular}} & Zeměkoule. \\
\hline & $\begin{array}{l}\text { Budovat uvědomění, že člověk je stále závislý } \\
\text { na př́rodě a jejím bohatství. }\end{array}$ \\
\hline & Upřednostňovat místní výrobky. \\
\hline & Učit se hodnotit technologie TUR. \\
\hline & $\begin{array}{l}\text { Budovat uvědomění, že štěstí a úspěch nemá } \\
\text { jen materiální podstatu. }\end{array}$ \\
\hline & $\begin{array}{l}\text { Naučit se šetřit potravinami, i když máme } \\
\text { dost prostředkü. }\end{array}$ \\
\hline & Skromnost. \\
\hline & $\begin{array}{l}\text { Předcházení vzniku odpadků, není ostuda } \\
\text { používat nenové věci. }\end{array}$ \\
\hline \multirow{5}{*}{$\begin{array}{l}\text { Rozvíjet ekologickou } \\
\text { etiku } \\
\text { a zodpovědnost. }\end{array}$} & $\begin{array}{l}\text { Učit se lásce k přírodě a jejím částem, soucit } \\
\text { s trpícími tvory. }\end{array}$ \\
\hline & Budovat úctu k životu (nejen lidskému). \\
\hline & $\begin{array}{l}\text { Učit se pravidla chování k př́rodě (netrápit, } \\
\text { neničit, neobtěžovat). }\end{array}$ \\
\hline & $\begin{array}{l}\text { Rozvíjet ekologické svědomí - cítit vinu, když } \\
\text { se prohřešujeme proti zásadám TUR. }\end{array}$ \\
\hline & $\begin{array}{l}\text { Vést k odpovědnosti ve vztahu k biosféře, } \\
\text { k ochraně prírody a přírodních zdrojŭ - } \\
\text { zodpovědnost za prírodu, hrdost - i já jsem } \\
\text { důležitý. }\end{array}$ \\
\hline \multirow[b]{2}{*}{ Zdravý životní styl. } & $\begin{array}{l}\text { Vztah pobytu a pohybu na čerstvém vzduchu } \\
\text { a zdraví. }\end{array}$ \\
\hline & Vztah zdravého stravování a zdraví. \\
\hline \multirow{6}{*}{ Znalosti. } & $\begin{array}{l}\text { Postupně poznávat světové biotopy a jejich } \\
\text { obyvatele (biomy Země). }\end{array}$ \\
\hline & $\begin{array}{l}\text { Znalost vybraných českých živočichů. Ne moc, } \\
\text { ale ty dobře znát. Postupně více. }\end{array}$ \\
\hline & $\begin{array}{l}\text { Znalost českých ekosystémů (les, louka, pole, } \\
\text { zahrada aj. - viz RVP) a umět zařadit rostliny } \\
\text { a živočichy, kteří v nich žijí. }\end{array}$ \\
\hline & $\begin{array}{l}\text { Vědět, co se v přírodě rozloží a za jak dlouho } \\
\text { a co ne. }\end{array}$ \\
\hline & $\begin{array}{l}\text { Seznamovat se se základními ději v prírodě } \\
\text { (koloběh vody, potravní řetězce). }\end{array}$ \\
\hline & Základy legislativy ochrany ž. p. a přírody. \\
\hline
\end{tabular}




\begin{tabular}{|c|c|c|}
\hline & & $\begin{array}{l}\text { Vědět, že škůdci nejsou jen škůdci - každý } \\
\text { tvor má v ekosystému svůj smysl. }\end{array}$ \\
\hline & & Vhled do technologií. \\
\hline & \multirow{5}{*}{$\begin{array}{l}\text { Dovednosti } \\
\text { (základy vědeckého } \\
\text { zkoumání). }\end{array}$} & Pozorování. \\
\hline & & Pokusy. \\
\hline & & Práce s lupou a mikroskopem. \\
\hline & & $\begin{array}{l}\text { Základy práce s literaturou a jinými } \\
\text { informačními zdroji. }\end{array}$ \\
\hline & & $\begin{array}{l}\text { Základy zaznamenávání (zápisy, tabulky, } \\
\text { grafy). }\end{array}$ \\
\hline & Kritické myšlení. & $\begin{array}{l}\text { Rozvoj kritického myšlení (chápáno více jako } \\
\text { „selský rozum", než jako technika RWCT). }\end{array}$ \\
\hline \multirow{19}{*}{ PROSTŘEDKY } & \multirow{3}{*}{$\begin{array}{l}\text { Příjemná atmosféra } \\
\text { v hodinách EV } \\
\text { (pozitivní sociální } \\
\text { klima třídy). }\end{array}$} & Legrace. \\
\hline & & Využití prvků dramatické výchovy. \\
\hline & & Diskuse, prostor pro otázky i odpovědi dětí. \\
\hline & \multirow{10}{*}{$\begin{array}{l}\text { Vycházet vstříc } \\
\text { učebním stylưm a } \\
\text { obecným edukačním } \\
\text { potřebám dětí tohoto } \\
\text { věku. }\end{array}$} & Podchycení skrze dominantní zájem dítěte. \\
\hline & & Pozorovat, resp. učit pozorovat. \\
\hline & & Informace dětem správně zjednodušovat. \\
\hline & & Nechat manipulovat, sáhnout. \\
\hline & & Vzbudit u žáků zvídavost - učit je objevovat. \\
\hline & & Rozumová výuka. \\
\hline & & $\begin{array}{l}\text { Od poznávání ke znalostem, dovednostem } \\
\text { a návykům. }\end{array}$ \\
\hline & & $\begin{array}{l}\text { Podporovat a rozvíjet tvořivost a praktickou } \\
\text { inteligenci. }\end{array}$ \\
\hline & & Umožnit dětem prožitky. \\
\hline & & Poznávat svět všemi smysly. \\
\hline & \multirow{5}{*}{$\begin{array}{l}\text { Vycházet } z \text { přírody } \\
\text { v časovém a } \\
\text { regionálním kontextu. }\end{array}$} & Návaznost na roční období. \\
\hline & & Společné obdivování přírody a jejích proměn. \\
\hline & & $\begin{array}{l}\text { Umožnit dětem kontakt s hospodářskými } \\
\text { zvířaty. }\end{array}$ \\
\hline & & $\begin{array}{l}\text { Seznámení s existencí ekosystémů (zařazení } \\
\text { zvířat a rostlin do jejich přirozeného prostředí) } \\
\text { a nácvik jejich rozpoznávání v krajině. }\end{array}$ \\
\hline & & $\begin{array}{l}\text { Demonstrace na konkrétních příkladech } \\
\text { z okolí školy a domovů dětí (památné stromy, } \\
\text { studánky, konkrétní zvíre). }\end{array}$ \\
\hline & Společná práce. & Společná fyzická práce v přírodním terénu. \\
\hline
\end{tabular}




\begin{tabular}{|c|c|c|}
\hline & & $\begin{array}{l}\text { Rozvíjet, podporovat a oceňovat tzv. } \\
\text { praktickou inteligenci. }\end{array}$ \\
\hline & & $\begin{array}{l}\text { Žáci skutečně pracují (nestačí, když se dívají, } \\
\text { popisují či kreslí činnost). }\end{array}$ \\
\hline & $\begin{array}{l}\text { Zprostředkovat } \\
\text { ekonomický dopad } \\
\text { šetrného chování. }\end{array}$ & $\begin{array}{l}\text { Zažívat pozitivní ekonomický dopad } \\
\text { (peníze za sběr využít podle přání žáků). }\end{array}$ \\
\hline & & $\begin{array}{l}\text { Upřednostnit hry v přírodě (skautské, } \\
\text { Zapletalovy). }\end{array}$ \\
\hline & 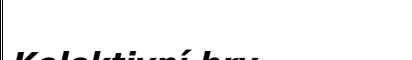 & Nesoutěživé (žák překonává sám sebe). \\
\hline & 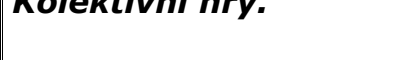 & Důraz na spolupráci žáků. \\
\hline & & $\begin{array}{l}\text { Simulační } \\
\text { (k demonstraci environmentálních problémů). }\end{array}$ \\
\hline & & Čtení příběhů z knížek o přírodě. \\
\hline & & $\begin{array}{l}\text { Vzájemné vyprávění autentických zážitků } \\
\text { z př́rody. }\end{array}$ \\
\hline & & Společné naslouchání přírodě. \\
\hline & Narativní metoda. & $\begin{array}{l}\text { Učit se získávat informace př́mo z přírody } \\
\text { (květina potřebuje zalít, stromek podepřít, } \\
\text { kráva nakrmit). }\end{array}$ \\
\hline & & Učit se diskutovat o problému. \\
\hline & & Etiketa posluchače (nerušit, vhodně se ptát). \\
\hline & 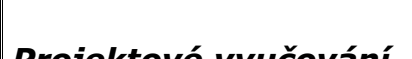 & Interdisciplinarita. \\
\hline & 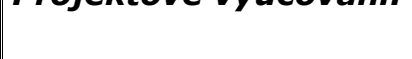 & Projekty krátkodobé i dlouhodobé. \\
\hline & Hodnocení & Laskavé hodnocení (slovní nebo portfoliové). \\
\hline & výchovy. & Nesmí odradit (vzbudit biofobii). \\
\hline & Charakterové a & $\begin{array}{l}\text { Entuziasmus, zapálení pro věc, i kdyby jen } \\
\text { pro jeden druh. }\end{array}$ \\
\hline & & Př́tel, průvodce, ne nadřazený despota. \\
\hline & & Znalost trídního kolektivu a vazeb v něm. \\
\hline & Vztah učitel - žák - & $\begin{array}{l}\text { Reflexe znalostí, zkušeností a zážitků, které } \\
\text { rodiny poskytují dětem. }\end{array}$ \\
\hline & & $\begin{array}{l}\text { Začlenění zážitků, zkušeností i znalostí } \\
\text { získaných v rodině do vzdělávacího procesu. }\end{array}$ \\
\hline & Schopnost učitele & Spolupráce s rodiči - odborníky. \\
\hline & $\begin{array}{l}\text { a spolupracovat. } \\
\text { Celoživotní vzdělávání }\end{array}$ & $\begin{array}{l}\text { Spolupráce s ostatními učiteli a personálem } \\
\text { školy. }\end{array}$ \\
\hline & učitelů. & Spolupráce se SEV a ekocentry. \\
\hline
\end{tabular}




\section{Diskuse}

\section{Komparace s již existujícími materiály}

Ve srovnání s Ekopedagogovým osmerem (Máchal, 20004) se shodují témata: přímé kontakty s přírodou, návaznost na RVP využití aktivizujících forem výuky, interdisciplinarita rozvíjení kritického myšlení, prostředí ekoprogramu, terénní výuka, přírodniny, odborná správnost, výrobek z přírodního materiálu, rozvoj citového vztahu k prírodě, rozvoj klíčových kompetencí. Ekopedagogovo osmero obsahuje navíc požadavek „vymezení spolupráce s doprovázejícím pedagogem" a "závěrečné opakování na konci programu”. Ekopedagogovo osmero ovšem nebylo koncipováno jako výčet všech pojmů.

Komparací Seznamu ÉČEK a kapitoly Environmentální výchova v RVP ZV (2004) vzniklo několik doporučení pro budoucí aktualizaci RVP ZV. Vhodné by bylo definování cílů environmentální výchovy - $v$ současnosti je pedagog nucen cíle transformovat $z$ tzv. "Přínosů environmentální výchovy", ale i ty jsou formulovány příliš vágně a umožňují nejednotný výklad (Jančaříková, 2006). Dále by bylo vhodné do obsahu environmentální výchovy uvedeného v RVP ZV (2004) začlenit téma „zahrada", které je z mnoha důvodů (např. možnost bezpečného samostatného zkoumání) pro žáky prvního stupně tématem klíčovým (srov. Burešová, 2007) -Požadavky na znalosti a obsah environmentální výchovy jsou v RVP ZV značné, hrozí reálné riziko, že neinformovaný učitel/učitelka bude za základ environmentální výchovy považovat právě a jenom předání znalostí. RVP ZV nevěnuje dostatek pozornosti problematice trvale udržitelného rozvoje, což je, vzhledem k nadnárodním dokumentům, systémová chyba. RVP ZV se nevěnuje hodnocení environmentální výchovy (ani ostatních prưřezových témat), což vzhledem k tomu, že jde o naprosto novou koncepci, způsobí jistě mnoho problémů.

Komparací Seznamu ÉČEK s Teorií a metodikou ekologické výchovy H. Horké (1996) byla nalezena shodná témata: interdisciplinarita (včetně výtvarné a hudební výchovy), komplexní přístup (porozumění cyklům a vztahům), využití znalosti a péče o nejbližší okolí školy, návaznost na roční období všemi smysly, vyprávění př́běhů (bez teorie), rozvíjení úcty k životu, rozvíjení zaujetí pro živé organismy, prosazování zásad TUR, chápání druhů v kontextu jejich přirozených ekosystémů, potřeba vycházet vstříc obecným edukačním potřebám dětí tohoto věku (respekt a podpora zvídavosti a činorodosti, principu prožitku, apod.), princip pozitivní motivace a odmítnutí negativní motivace (strašení katastrofami). Témata $\mathrm{H}$. Horkou nedoceněná, resp. neřešená (což souvisí nepochybně s rokem vydání publikace): vyučování $v$ terénu (pod širým nebem a v expozicích), využití techniky, vybavení třídy (se všemi podsložkami viz tabulka 2: zvíře ve třídě, časové schéma evoluce, vztah pobytu a pohybu ve venkovním prostředí a zdraví žáků, využití školních zahrad, vztah zdravého stravování a zdraví žáků, pokusy, práce s lupou, dalekohledem a mikroskopem, potřeba vycházet vstříc učebním stylům (neřeší prírodovědnou inteligenci), změny chování dětí, proces odcizování přírodě, potenciál rodičů, společná práce, environmentální ekonomie a problematika hodnocení environmentální výchovy.

Metodický pokyn MŠMT (ř́ijen 2008) byl vytvářen mimo jiné také na základě zde prezentovaného výzkumu. ${ }^{5}$ Přesto se v něm objevuje jedno další významné "ÉČKO": osvojení si praktických dovedností pro chování a pobyt v přírodě (tábornické dovednosti).

\section{Další využití Seznamu ÉČEK}

Seznam ÉČEK slouží jako ucelený popis ideálního stavu realizace environmentální výchovy na prvním stupni ZŠ.

\footnotetext{
${ }^{4}$ A také verze z roku 2004. Poslední verze (2009) nebyla při provádění komparace $k$ dispozici.

5 Jeden z respondentů-expertů byl v týmu, který připravoval tento pokyn; předběžné výsledky, které mu byly zaslány ke komentáři, se svolením autora využil
} 
Ve výzkumné práci posloužil Seznam ÉČEK jednak jako linie následného výzkumu, jednak jako vodítko při konstrukci Konceptu environmentální výchovy na prvním stupni ZŠ́ (Jančař́ková, 2008: str. 127 nn).

Modifikací výčtu pojmů (Seznamu ÉČEK) byl vytvořen nástroj autoevaluace environmentální výchovy pro učitele (popř. lektory) environmentální výchovy, prostřednictvím něhož byla hodnocena kvalita EV na prvním stupni ZŠ pro potřeby výzkumu (Jančaříková 2008); v nejbližší době bude nabídnut Pavučině a střediskưm EV k diskusi a k širšímu využívání.

Dále by na jeho základě mohly být vytvořeny také nástroje evaluace učitelů, resp. lektorů environmentální výchovy.

\section{Závěr}

Úroveň environmentální výchovy v současné české škole je různá, většinou nedostatečná. Zásady trvale udržitelného chování, resp. života jsou předávány především formálně (hovoří se o nich, ale nejsou realizovány). Učitelé nedokážou problematiku chápat a řešit komplexně (např. pod environmentální výchovou si představují spíše předávat soucit s „myšičkou" nebo „holoubkem", které ulovila „zlá sova", než zásadní změnu vlastního chování), často se chaoticky věnují jednotlivým tématưm a prvkům v projektech (oblíbená témata jsou voda, třídění odpadu), jejichž kvalita i účinnost je sporná (např. se žáci dozvědí, že se do směsného odpadu nehází papír, ale už se nedozvědí, že se do něj skutečně nesmí házet baterie, monočlánky, léky či zbytky barev).

Z dalších výzkumů vyplývá, že naprosto nedostatečný je systém hodnocení environmentální výchovy. Tento stav není ovšem vázán jen na českou školu environmentální výchovy, ale je obecný (Wilke, 1993: str. 152 nn).

Učitelé/učitelky nemají v současné době představu, jaké nástroje jsou k hodnocení environmentální výchovy vhodné. Naprostá většina z nich environmentální výchovu vưbec nehodnotí, resp. užívá demotivující nástroje hodnocení (známkování škálou 1-5; obvykle ovšem ne za znalosti, resp. za trvale udržitelné chování, ale za chování nezatěžující učitele $v$ hodinách).

Existuje ovšem celá řada zapálených učitelů a učitelek a dalších pedagogických pracovníků - úžasných osobností, kteří se žákům obětavě věnují, kteří mají chut' environmentální výchovu realizovat co nejlépe a kteří stojí o další vzdělávání $v$ tomto oboru a kteří jsou potencionálem dalšího rozvoje tohoto oboru (Jančaříková, 2008: str. 28)

Příspěvek představuje výzkum, který by měl přispět k zefektivnění environmentální výchovy na prvním stupni ZŠ. Seznam ÉČEK zde představený bude samozrejmě dříve či později nutné aktualizovat, ale $v$ současné době by měl být nejucelenějším popisem ideální realizace environmentální výchovy na prvním stupni ZŠ.

\section{Seznam použité literatury}

- BUREŠOVÁ, K. (ed.), (2007). Učíme se v zahradě. Chaloupky: Chaloupky.

- Č̌inčera, J. (2007). Environmentální výchova : Od cílů k prostředkům. Brno: Paido.

- Činčera, J. (2009). Analýza prưřezového tématu Environmentální výchova v Rámcovém vzdělávacím programu pro základní vzdělávání. Envigogika, 4(1), Retrieved from http://www.envigogika.cuni.cz/index.php/Envigogika/article/view/33 http://dx.doi.org/10.14712/18023061.33 
- Horká, H. (1996). Teorie a metodika ekologické výchovy. Brno: Paido.

- Jančaříková, K. (2007). Úcta k životu - jeden z cílů Environmentální výchovy v RVP a Ize se s ní ve školní praxi vypořádat?. Envigogika, 2, Retrieved from http://www.envigogika.cuni.cz/index.php/cs/inspirace/20072/104-ucta-k-ivotu-jeden-z-cilenvironmentalni-vychovy-v-rvp-a-Ize-se-s-ni-ve-kolni-praxi-vypoadat

- Librová, H. (1994). Pestří a zelení : Kapitoly o dobrovolné skromnosti. Brno: Veronica, Hnutí Duha.

- Máchal, A. (2000) Ekopedagogovo osmero. In Průvodce praktickou ekologickou výchovou (pp. 80-902954). Brno: Rezekvítek, Lipka.

- Strauss, A., Corbin, J., (1998). asics of Qualitative Research: Techniques and Procedures for Developing Grounded Theory. London: ISBN.

- Strauss, A., Corbinová, J., (1999). Základy kvalitativního výzkumu. Brno: Podané ruce.

- Wilke, R. J. (ed.), (1993). Environmental education: Teacher Resource Handbook: A practical Guide for K - 12 Environmental Education. Thousand Oaks: Corwin press.

- Rámcový vzdělávací program pro základní vzdělávání (2004). : Výzkumný ústav pedagogický v Praze. Retrieved from http://www.vuppraha.cz/ 
Časopis Envigogika vydává Centrum pro otázky životního prostředí UK. Vývoj časopisu je podpořen projektem OP VK Mezioborová sít udržitelného rozvoje.

Více najdete na internetových stránkách projektu mosur.czp.cuni.cz
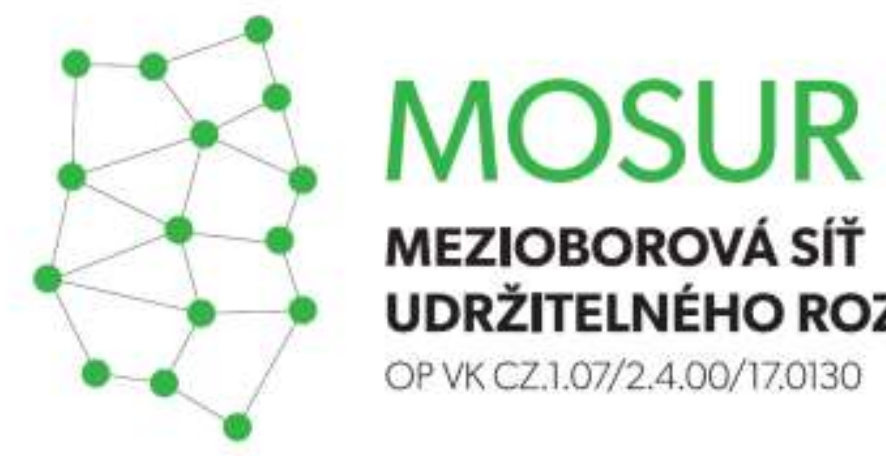

\section{MEZIOBOROVÁ SÍT} UDRŽITELNÉHO ROZVOJE

OP VK CZ.1.07/2.4.00/17.0130
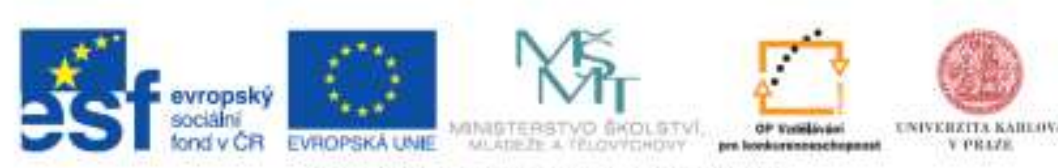

INVESTICE DO ROZVOUE VZDELAVANI 